\title{
PENGARUH KERJA SHIFT TERHADAP KELELAHAN PERAWAT DI RUANG RAWAT INAP RSUP HAJI ADAM MALIK MEDAN
}

\author{
Netty Panjaitan, Doni Simatupang \\ Jurusan Keperawatan Poltekkes Kemenkes Medan
}

\begin{abstract}
Abstrak
Kelelahan mengaruh pada kondisi melemahnya tenaga untuk melakukan suatu kegiatan,dapat berupa kelelahan fisiologis dan psikologis. Kelelahan fisiologis timbul karena adanya perubahan fisiologis dalam tubuh. Penurunan motivasi dan adanya penurunan produktivitas kerja. Rumah sakit adalah salah satu institusi pelayanan Kesehatan yang beroperasi 24 jam dimana perawat merupakan ujung tombak pelayanan kesehatan. Pelayanan keperawatan tidak terlepas dari pengaturan jam kerja/shift kerja. Dampak dari adanya sistem kerja yang terdiri dari shift merupakan faktor resiko terjadinya ssgangguan kesehatan,berupa gangguan pencernaan,gangguan tidur dan kelelahan. Tujuan penelitian mengetahui pengaruh kerja shift pagi,sore,malam,terhadap kelelahan. Metoda penelitian ini bersifat analitik dengan uji test berpasangan. Sampel diambil dengan cara purporsive sampling. Jumlah sampel sebanyak 30 orang terdiri dari shift pagi,sore,malam. Pengukuran kelelahan perawat dilakukan sebelum menjalankan kerja shift dan membandingkan dengan hasil pengukuran sesudah menjalankan kerja shift,berupa pengukuran subjektif dengan menggunakan IFRC (International Fatique Reaction Commite) dan pengukuran objektif dengan melakukan pengukuran kelelahan dengan Lakassida 77 Reaction Timer,yang hasilnya ada pengaruh kerja shift pagi,sore,malam terhadap kelelahan,tapi paling besar pengaruhnya pada shift malam. Hasil analisa statistik didapat $\mathrm{p} \leq$ masing $0.037,0.010,0.005$ yang arti nya ada pengaruh kerja shift pagi,sore,malam terhadap kelelahan perawat lebih kecil dari 0,05.
\end{abstract}

Kata kunci : Kerja shift, Kelelahan

\section{PENDAHULUAN}

\section{Latar Belakang}

Undang-undang No. 13 tahun 2003 tentang ketenagakerjaan dalam pasal 86 menyatakan bahwa tenaga kerja berhak mendapat perlindungan atas keselamatan dan kesehatan kerja, moral dan kesusilaan serta perlakuan yang sesuai dengan harkat dan martabat manusia serta nilai - nilai agama. Rumah sakit adalah salah satu pelayanan yang beroperasi 24 jam dimana pelayanan tersebut dilaksanakan oleh pekerja kesehatan rumah sakit. Pekerja kesehatan rumah sakit yang terbanyak adalah perawat yang berjumlah sekitar $60 \%$ dari tenaga kesehatan yang ada di rumah sakit. Perawat merupakan salah satu pekerja kesehatan yang selalu ada di setiap rumah sakit dan merupakan ujung tombak pelayanan kesehatan rumah sakit.

Pekerjaan seorang perawat dalam memberikan pelayanan keperawatan tidak terlepas dari pengaturan jam kerja di suatu rumah sakit yang lebih dikenal dengan istilah shift kerja. Shift kerja dapat berperan penting terhadap permasalahan pada manusia yang dapat meluas menjadi ganguan tidur (60 - 80\%), gangguan kesehatan fisik dan psikologi serta gangguan sosial maupun kehidupan keluarga. United Electrical (UE) News Health and Safety (1998) melaporkan bahwa dalam jangka waktu yang lama kerja shift dapat mengakibatkan gangguan pencernaan, gangguan tidur dan kelelahan.
RSUP Haji Adam Malik Medan merupakan sarana pelayanan yang bekerja selama 24 jam , dan adanya pelayanan 24 jam tersebut kegiatan diatur dengan sistem shift. Perawat Pelaksana bekerja 6 hari / minggu dengan pembagian shift sebagai berikut : shift pagi yaitu pukul 07.45 - 14.30 WIB, shift siang pada pukul 14.30 - 20.00 dan shift malam pada pukul 20.00 -08.00 WIB. Sistem shift yang digunakan terdiri dari kelompok shift dimana setiap kelompok diatur 2 hari bekerja shift malam, libur 1 hari dan dilanjutkan bekerja shift pagi atau shift sore tergantung kebutuhan perawatan diruangan. Meskipun telah diatur dengan shift ternyata pada masih ditemukan keluhan kelelahan pada perawat seperti adanya gejala sakit setelah shift malam, penurunan konsentrasi, pusing, sering menguap, mengantuk dan lelah seluruh badan.

Kerja shift dianggap adalah solusi untuk pekerjaan yang terus menerus, sudah diberikan libur yang cukup tetapi masih ada keluhan kelelahan. Untuk itu dirasa perlu untuk meneliti apakah ada pengaruh kerja shift terhadap kelelahan perawat dan untuk mengetahui kelompok shift yang paling banyak mengalami kelelahan.

Kelelahan didefenisikan sebagai suatu pola yang timbul pada suatu keadaan yang secara umum terjadi pada individu yang telah tidak sanggup lagi untuk melakukan aktivitasnya. Beberapa macam kelelahan kerja diakibatkan beberapa faktor antara lain lelah otot, lelah visual, lelah mental dan lelah monotonis. 
Kelelahan dapat disebabkan beberapa hal, tetapi yang paling sering disebabkan oleh monotonitas, intensitas kerja yang terlalu besar dan durasi kerja yang terlalu lama, lingkungan dan suasana kerja, fisiologi tubuh , sakit dan masalah nutrisi (Sudirman dan Sumakmur, 2002). Kelelahan yang disebabkan faktor fisik seperti suhu, penerangan, mikroorganisme, zat kimia, kebisingan dan circardian rhythms (terutama pada perawat shift malam) sedangkan kelelahan non fisik disebabkan oleh faktor psikososial baik ditempat kerja maupun dirumah atau masyarakat sekeliling.

\section{TINJAUAN PUSTAKA}

\subsection{Kerja Shift}

malam, yang juga merupakan salah satu faktor resiko terjadinya penurunan derajat kesehatan tenaga kerja dan juga berpengaruh terhadap produktifitas kerja.

Shift kerja adalah semua pengaturan jam kerja, sebagai pengganti atau tambahan kerja siang hari sebagaimana biasa dilakukan. Defenisi lain menyatakan bahwa shift kerja adalah pekerjaan yang secara permanen atau sering pada jam kerja yang tidak teratur (Kuswadji, 1997). Kerja shift pada perawat sebagai petugas kesehatan dapat menimbulkan dampak negatif dan mempengaruhi derajat kesehatan mereka. Mereka selalu berhubungan dengan berbagai bahaya potensial, dimana bila tidak diantisipasi dengan baik dan benar dapat mempengaruhi kesehatan dan keselamatan kerjanya (Depkes ,2003).

Sikap Perawat terhadap Shift kerja , adalah sebagai berikut :

1. Shift pagi : memberikan waktu luang baik untuk kehidupan keluarga dan kehidupan sosial

2. Shift sore : kehidupan sosial terbatas, waktu sore terbuang dan sedikit lelah

3. Shift malam : lelah, kehidupan social terbatas, kurang baik untuk kehidupan keluarga, gangguan tidur, memberikan banyak waktu luang terbuang.

Efek shift kerja menurut Fish (dalam Heri Firdaus, 2005), adalah sebagai berikut :

1. Efek Fisiologis mencakup kualitas tidur:

- Tidur siang tidak seefektif tidur malam, banyak gangguan dan biasanya diperlukan waktu istirahat untuk menebus kurang tidur malam

- Menurunnya kapasitas kerja fisik akibat timbulnya perasaan mengantuk dan lelah

- Menurunnya nafsu makan dan gangguan pencernaan..

2. Efek Psikososial menunjukkan efek yang lebih besar dari efek fisiologis, yaitu gangguan kehidupan keluarga, hilangnya waktu luang, kecil kesempatan berinteraksi dengan teman dan mengganggu aktivitas kelompok dalam masyarakat.

3. Efek Kinerja : kinerja menurun selama shift malam yang diakibatkan oleh efek fisiologis dan psikososial. Penurunan kinerja ini mengakibatkan kemampuan dapat mengakibatkan kemampuan mental menurun yang berpengaruh terhadap perilaku kewaspadaan pekerjaan, seperti kualitas kendali dan pemantauan.

4. Efek terhadap Kesehatan.

Shift kerja menyebabkan gangguan gastro intestinal, masalah ini cenderung terjadi pada usia 40-50 tahun. Shift kerja juga dapat menjadi masalah terhadap keseimbangan kadar gula dalam darah, bagi penderita diabetes.

5. Efek terhadap keselamatan kerja

Survey pengaruh shift kerja terhadap Kesehatan dan keselamatan kerja yang dilakukan ( Smith at. All, 2007) melaporkan frekwensi kecelakaan paling tinggi terjadi pada akhir rotasi shift kerja (malam) dengan rata-rata jumlah kecelakaan $0.69 \%$ / tenaga kerja.

Secara umum, kinerja kerja shift dipengaruhi oleh kombinasi dari faktor-faktor berikut:

a) Tipe pekerjaan. Pekerjaaan yang menuntut secara mental (seperti inspeksi dan kontrol kualitas) memerlukan kesabaran dan kehatihatian. Pekerja shift mungkin akan kekurangan dua hal tersebut.

b) Tipe sistem shift. Gangguan irama tubuh (circadian rhythms) dapat menimbulkan kerugian terhadap kemampuan fisik dan mental pekerja shift, khususnya ketika perubahan shift kerja dan shift malam.

c) Tipe pekerja. Untuk contoh, pekerja yang telah berusia tua memiliki kemampuan yang minimal untuk untuk menstabilkan irama tubuh ketika perubahan shift kerja.

Dalam penyusunan jadwal shift kerja ada beberapa saran yang harus diperhatikan dalam penyusunan jadwal:

1. Pekerja shift malam sebaiknya berumur 25-50 tahun.

2. Pekerja yang cenderung punya penyakit di perut dan usus, serta yang punya emosi tidak stabil disarankan utk tidak ditempatkan di shift malam.

3. Pekerja yang tinggal jauh dari tempat kerja atau berada dilingkungan ramai tidak dapat bekerja malam.

4. Sistem shift 3 rotasi sebaiknya pukul 07.00-5.0023.00 atau $08.00-16.00-24.00$.

5. Rotasi pendek lebih baik daripada rotasi panjang dan harus dihindarkan kerja malam secara terus menerus.

6. Rotasi yang baik 2-2-2 (metropolitan pola atau 22-3 (continental pola).

7. Kerja malam 3 hari berturut-turut harus segera diikuti istirahat paling sedikit 24 jam.

8. Perencanaan shift meliputi akhir pekan dengan 2 hari libur berurutan.

9. Tiap shift terdiri dari satu kali istirahat yang cukup utk makan.

\subsection{Kelelahan Kerja}

Kelelahan kerja merupakan komponen kelelahan fisiologis dan psikologis. Kerja fisik terus menerus dan memerlukan konsentrasi dapat diukur dengan perubahan fisiologis dalam tubuh yaitu penurunan waktu reaksi dan perubahan psikologis yaitu adanya perasaan lelah, khususnya bagi tenaga kerja Indonesia. Faktor individu seperti umur juga dapat berpengaruh 
terhadap waktu reaksi dan perasaan lelah tenaga kerja (Setyawati, 2003). Kelelahan dapat disebabkan oleh beberapa faktor antara lain rotasi shift kerja, faktor individu (kesehatan/ penyakit, jenis kelamin, umur, pendidikan, beban kerja, masa kerja dan status gizi) dan faktor lingkungan fisik (kebisingan, penerangan, suhu dan tekanan panas, vibrasi dan ventilasi).

\subsubsection{Faktor-faktor yang berkaitan dengan terjadinya kelelahan}

Faktor-faktor yang berkaitan dengan terjadinya kelelahan (Granjean, 1998) adalah sebagai berikut : kelelahan merupakan hasil dari berbagai ketegangan yang dialami tubuh sehari-hari. Untuk mempertahankan kesehatan dan efisiensi banyaknya istirahat dan pemulihan harus seimbang dengan tingginya ketegangan kerja. Penyegaran terjadi terutama selama waktu tidur malam, tetapi periode istirahat dan waktu berhenti juga dapat memberi penyegaran

Kelelahan adalah proses yang mengakibatkan penurunan kesejahteraan,kapasitas atau kinerja sebagai akibat dari aktivitas kerja (Mississauga, 2012). Kata "lelah" memiliki arti tersendiri bagi setiap individu, bersifat subjektif dan menurunkan produktivitas (Putri,2008). Investigasi di beberapa negara menunjukkan bahwa Kelelahan (fatigue) memberi kontribusi yang signifikan terhadap kecelakaan kerja (Eraliesa, 2008). Kelelahan kerja memberi kontribusi 50\% terhadap terjadinya kecelakaan kerja (Maurits, 2008).

Menurut Suma'mur (1996) ada 30 gejala kelelahan yang terbagi dalam 3 kategori yaitu :

1) Menunjukkan terjadinya pelemahan kegiatan. Perasaan berat di kepala, menjadi lelah seluruh badan, kaki merasa berat, sering menguap, merasa kacau pikiran, manjadi mengantuk, marasakan beban pada mata,kaku dan canggung dalam gerakan, tidak seimbang dalam berdiri, mau berbaring.

2) Menunjukkan terjadinya pelemahan motivasi.

Merasa susah berpikir, lelah berbicara, menjadi gugup, tidak berkonsentrasi, tidak dapat mempunyai perhatian terhadap sesuatu, cenderung untuk lupa, kurang kepercayaan, cemas terhadap sesuatu, tidak dapat mengontrol sikap, tidak dapat tekun dalam pekerjaan.

3) Menunjukkan gambaran kelelahan fisik akibat keadaan umum.

Sakit kepala, kekakuan di bahu, merasa nyeri di punggung, terasa pernafasan tertekan, haus, suara serak, terasa pening, spasme dari kelopak mata, tremor pada anggota badan, merasa kurang sehat.

Kelelahan yang terus menerus terjadi setiap hari akan berakibat terjadinya kelelahan yang kronis. Perasaan lelah tidak saja terjadi sesudah bekerja pada sore hari, tetapi juga selama bekerja, bahkan kadang-kadang sebelumnya. Perasaan lesu tampak sebagai suatu gejala. Gejala-gejala psikis ditandai dengan perbuatan perbuatan anti sosial dan perasaan tidak cocok dengan sekitarnya, sering depresi,kurangnya tenaga serta kehilangan inisiatif. Tanda-tanda psikis ini sering disertai kelainan-kelainan psikosomatis seperti sakit kepala, vertigo, gangguan pencernaan,tidak dapat tidur dan lain-lain. Kelelahan kronis demikian disebut kelelahan klinis. Hal ini menyebabkan tingkat absentisme akan meningkat terutama mangkir kerja pada waktu jangka pendek disebabkan kebutuhan istirahat lebih banyak atau meningkatnya angka sakit. Kelelahan klinis terutama terjadi pada mereka yang mengalami konflik-konflik mental atau kesulitan-kesulitan psikologis. Sikap negatif terhadap kerja, perasaan terhadap atasan atau lingkungan kerja memungkinkan faktor penting dalam sebab ataupun akibat (Suma’mur, 1996).

\subsubsection{Konsekwensi Kelelahan Kerja}

Konsekwensi kelelahan kerja menurut Randal Schuller (1999) antara lain :

- Pekerja yang mengalami kelelahan kerja akan berprestasi lebih buruk lagi daripada pekerja yang penuh semangat

- Memburuknya hubungan pekerja dengan pekerja lain

- Dapat mendorong terciptanya tingkah laku yang menyebabkan menurunnya kualitas hidup rumah tangga seseorang

Kelelahan kerja yang tidak dapat diatasi akan menimbulkan berbagai permasalahan kerja yang fatal dan mengakibatkan kecelakaan kerja sehingga Rumah Sakit wajib mengetahui tingkat kinerja dan hal yang dapat menimbulkan permasalahan dalam bekerja, salah satunya kelelahan kerja pada perawat (Dian \& Solikhah, 2012).

Rumah Sakit merupakan sarana pelayanan kesehatan yang beroperasi 24 jam. Salah satu sumber daya yang dibutuhkan rumah sakit dalam perawatan pasien adalah perawat yang dalam segi jumlah menempati urutan teratas, khususnya bangsal rawat inap. Pekerjaan seorang perawat tidak terlepas dari sistem shift kerja (Dian \&Solikhah, 2012). Meskipun memberikan keuntungan terhadap pasien, shift kerja dapat memberikan dampak negatif yang salah satunya adalah kelelahan.

\subsection{Kerangka Konsep}

Variabel pada penelitian terdiri dari Variabel Independen, yaitu Perawat yang melaksanakan kerja shift pagi, kerja shift sore, kerja shift malam. Variabel Dependen adalah kelelahan perawat yang diukur dengan Kuesioner Alat Ukur Kelelahan Kerja yaitu untuk mengetahui Pengaruh shift kerja terhadap kelelahan pada perawat di RSUP Haji Adam Malik Medan, skemanya dapat dilihat sebagai berikut :

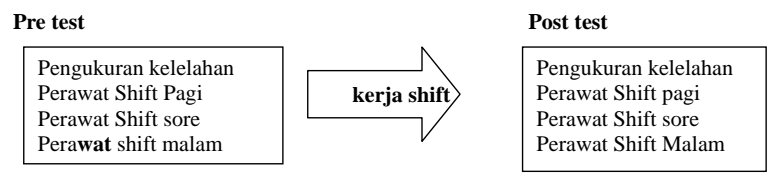

\section{TUJUAN DAN MANFAAT PENELITIAN}

\subsection{Tujuan Penelitian}

\section{2. Tujuan Khusus}

a. Mengetahui pengaruh kerja shift pagi terhadap kelelahan di Ruang Rawat Inap RSUP Haji Adam Malik Medan

b. Mengetahui pengaruh kerja shift sore terhadap kelelahan di Ruang Rawat Inap RSUP Haji Adam Malik Medan 
c. Mengetahui pengaruh kerja shift malam terhadap kelelahan di Ruang Rawat Inap RSUP Haji Adam Malik Medan

\subsection{Manfaat Penelitian}

Hasil penelitian ini diharapkan dapat menjadi sumbangan pemikiran bagi :

1. Manajer keperawatan dalam menyusun dan mengatur shift kerja Perawat di ruang rawat Inap.

2. Perawat yang menjalankan kerja shift.

3. Bagi pengembangan ilmu pengetahuan, untuk mencegah terjadinya gangguan kesehatan pada perawat yang menjalankan kerja shift

4. Untuk peneliti lain untuk melakukan penelitian yang lebih lanjut.

\section{METODE PENELITIAN}

\section{4 .1. Jenis dan Desain Penelitian}

Penelitian ini bersifat analisis dengan menggunakan uji t-test berpasangan untuk mengukur Kelelahan Perawat sebelum menjalankan kerja shift (pre test) dan dilakukan lagi setelah menjalankan kerja shift (post test). Selanjutnya dilakukan analisa terhadap hasil pengukuran kelelahan perawat di Ruang Rawat Inap RSUP Haji Adam Malik Medan.

\subsection{Lokasi Penelitian}

Penelitian ini dilaksanakan di Ruang Rawat Inap Penyakit Dalam dan Ruang Rawat Inap Terpadu Intena di RSUP Haji Adam Malik Medan

\subsection{Waktu Penelitian}

Waktu Penelitian dilaksanakan selama 12 minggu, direncanakan dimulai dari bulan September sampai dengan Oktober 2016

\subsection{Populasi dan Sampel}

Populasi dalam penelitian ini adalah semua Perawat yang bertugas diruang Rawat Inap Penyakit Dalam pada survey pendahuluan diketahui Perawat yang bertugas di tempat tersebut berjumlah 61 orang.

Tehnik Penentuan sampling adalah purposive sampling dan .yang menjadi sampel adalah perawat yang bekerja Shift pagi, Shift sore dan Shift Malam, di Rindu A pada ruang penyakit dalam wanita, pria,post operasi neurologi,ruang neurologi. Inklusi yang ditetapkan.

Adapun criteria inklusi sebagai berikut :

1. Perawat yang bekerja dengan shift

2. Bersedia menjadi Responden

Jumlah sampel pada perawat yang bekerja shift adalah. perawat yang terdiri dari shift pagi, shift siang dan shift malam sebanyak 30 orang.

\subsection{Tehnik Pengukuran}

Alur penelitian ini adalah pengumpulan bahan untuk tinjauan pustaka,pembuatan proposal penelitian dan permintaan prosedur perizinan penelitian ke RSUP Haji Adam Malik Medan. Setelah proses perizinan, dilakukan studi pendahuluan untuk melihat ada tidaknya kelelahan pada perawat. Pengumpulan data dilakukan dengan membagikan kuesioner (data subjektif) kepada perawat sebelum mulai bekerja dan sesudah selesai bekerja terhadap seluruh responden yang memenuhi kriteria inklusi. Pengumpulan data dilakukan dengan kuisioner Pengukuran Kelelahan Kerja dengan International Fatique Research Comitte Japenese Association of Industrial Health of Comitte (IFRC) dan pengumpulan data secara objektif melalui pengukuran kelelahan dengan alat Ukur Kelelahan berupa Reaction Timer Lakkasidaya 77 sebelum perawat mulai bekerja dan sesudah perawat selesai bekerja.

\section{HASIL DAN PEMBAHASAN}

\subsection{Gambaran Umum Lokasi Penelitian}

Penelitian ini dilaksanakan d. Rumah Sakit Umum Pusat H. Adam Malik Medan merupakan rumah sakit kelas A sesuai dengan SK Menkes no. 339/Menkes/SK/VIII/1990. Sebagai rumah sakit pendidikan sesuai dengan SK Menkes no. 502/Menkes/SK/-/1991. Rumah sakit ini berfungsi sejak tanggal 17 juni 1991 dengan pelayanan rawat jalan dan rawat inap.

Rumah Sakit Umum Pusat H. Adam Malik terdiri dari 14 poliklinik rawat jalan dan 2 instalasi ruang rawat inap adalah ruangan Rindu B ( terdiri dari RB1, RB2, RB3, daN RB4 ) dan ruangan Rindu A ( Terdiri dari RA1, RA2, RA3, RA4, dan RA5 ) Pelayanan kesehatan di Rindu B dan Rindu A ditangani oleh dokter spesialis,dokter umum, perawat dengan kualifikasi pendidikan S1 keperawatan, D3 keperawatan dan SPK, dimana pelayanan rawat inap dimulai sejak tanggal 2 Mei 1992.

Adapun Visi RSUP .H Adam Malik : Menjadi pusat rujukan pelayanan kesehatan pendidikan dan penelitian yang mandiri dan unggulan di Sumatera tahun 2015. Sedangkan Misi RSUP. H Adam Malik: melaksanakan pelayanan kesehatan yang paripurna, bermutu dan terjangkau, melaksanakan pendidikan, pelatiahan, serta penelitian kesehatan yang bersifat profesional, melaksanakan pelayanan kesehatan dengan prinsip efektif, efesien, akuntabel dan mandiri dengan motto PATEN ( Pelayanan cepat, Akurat, Terjangkau, Effisien, Nyaman).

\subsection{Hasil Penelitian}

Berdasarkan penelitian yang dilakukan di Ruang Inap terpadu ditemui pasien yang dirawat A1 : sebanyak 41 orang, di A2 dirawat sebanyak 31 pasien dan di Ruang Rawat Inap Bedah Syaraf dirawat pasien sebanyak 34 orang. Seluruh pasien yang dirawat memerlukan perawatan, total, partial dan minimal. Dari hasil wawancara dan pengisian kuesioner diperoleh hasil bahwa dari 30 Responden yang terdiri dari Perawat Penanggung Jawab 9 orang dan 21 orang perawat Pelaksana.Responden yang berusia $20 \mathrm{~s} / \mathrm{d} \quad 40$ tahun sebanyak 14 orang, yang berumur $>40$ s/d 50 tahun sebanyak 13 orang dan berusia $>50$ tahun sebanyak 3 orang, dengan pengalaman kerja yang bervariasi antara 5 s/d 30 tahun ( tabel 5.1). 
Tabel 5.1. Karakteristik Responden Perawat Kerja Shift Di Ruangan Interna RSUP .H.Adam Malik Medan Tahun 2016

\begin{tabular}{|c|c|c|c|c|c|c|c|c|c|c|}
\hline \multirow[t]{2}{*}{ N0 } & \multicolumn{3}{|c|}{ Umur (tahun) } & \multicolumn{2}{|c|}{ Jenis Kelamin } & \multicolumn{2}{|l|}{ Status } & \multicolumn{3}{|c|}{ Masa kerja } \\
\hline & $<25$ & $25-50$ & $>50$ & $\begin{array}{l}\text { Laki- } \\
\text { laki }\end{array}$ & $\begin{array}{l}\text { Perem } \\
\text { puan }\end{array}$ & Kawin & $\begin{array}{l}\text { Tidak } \\
\text { Kawin }\end{array}$ & $5-10$ & $10-20$ & $>20$ \\
\hline 1 & & 41 & & & $\sqrt{ }$ & $\sqrt{ }$ & & & $\checkmark$ & \\
\hline 2 & & 48 & & & $\sqrt{ }$ & & $\sqrt{ }$ & & & $\sqrt{ }$ \\
\hline 3 & & 50 & & & $\sqrt{ }$ & $\sqrt{ }$ & & & & $\sqrt{ }$ \\
\hline 4 & & 37 & & & $\sqrt{ }$ & & $\sqrt{ }$ & $\checkmark$ & & \\
\hline 5 & & & 53 & & $\sqrt{ }$ & $\sqrt{ }$ & & & $\checkmark$ & \\
\hline 6 & & 38 & & & $\sqrt{ }$ & & $\sqrt{ }$ & $\checkmark$ & & \\
\hline 7 & & 32 & & & $\sqrt{ }$ & $\sqrt{ }$ & & & & $\sqrt{ }$ \\
\hline 8 & & 32 & & & $\sqrt{ }$ & & $\sqrt{ }$ & & & \\
\hline 9 & & 30 & & & $\sqrt{ }$ & $\sqrt{ }$ & & $\checkmark$ & & \\
\hline 10 & & 41 & & & $\sqrt{ }$ & & $\sqrt{ }$ & & $\checkmark$ & \\
\hline 11 & & 36 & & & $\sqrt{ }$ & $\sqrt{ }$ & & & $\checkmark$ & \\
\hline 12 & & & 51 & & $\sqrt{ }$ & $\sqrt{ }$ & & & & $\sqrt{ }$ \\
\hline 13 & & 48 & & & $\sqrt{ }$ & $\sqrt{ }$ & & & $\checkmark$ & \\
\hline 14 & & 50 & & & $\sqrt{ }$ & $\sqrt{ }$ & & & & $\sqrt{ }$ \\
\hline 15 & & 36 & & & $\sqrt{ }$ & $\sqrt{ }$ & & $\checkmark$ & & \\
\hline 16 & & 29 & & & $\sqrt{ }$ & $\sqrt{ }$ & & $\checkmark$ & & \\
\hline 17 & & 43 & & & $\sqrt{ }$ & $\sqrt{ }$ & & & $\checkmark$ & \\
\hline 18 & & 28 & & & $\sqrt{ }$ & $\sqrt{ }$ & & $\checkmark$ & & \\
\hline 19 & & 45 & & & $\sqrt{ }$ & $\sqrt{ }$ & & & $\checkmark$ & \\
\hline 20 & & & 53 & & $\sqrt{ }$ & $\sqrt{ }$ & & & & $\sqrt{ }$ \\
\hline 21 & & 49 & & & $\sqrt{ }$ & $\sqrt{ }$ & & & & $\sqrt{ }$ \\
\hline 22 & & 28 & & $\sqrt{ }$ & 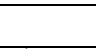 & $\sqrt{ }$ & & $\checkmark$ & & \\
\hline 23 & & 37 & & & $\sqrt{ }$ & $\sqrt{ }$ & & & $\checkmark$ & \\
\hline 24 & & 48 & & & $\sqrt{ }$ & $\sqrt{ }$ & & & $\checkmark$ & \\
\hline 25 & & 34 & & & $\sqrt{ }$ & $\sqrt{ }$ & & $\checkmark$ & & \\
\hline 26 & & 37 & & & $\sqrt{ }$ & $\sqrt{ }$ & & $\checkmark$ & & \\
\hline 27 & & 38 & & & $\sqrt{ }$ & $\sqrt{ }$ & & & $\checkmark$ & \\
\hline 28 & & 29 & & & $\sqrt{ }$ & & $\sqrt{ }$ & $\checkmark$ & & \\
\hline 29 & & 46 & & & $\sqrt{ }$ & & $\sqrt{ }$ & & $\checkmark$ & \\
\hline 30 & & 39 & & & $\sqrt{ }$ & $\sqrt{ }$ & & $\checkmark$ & & \\
\hline Total & - & 27 & 3 & 1 & 29 & 23 & 7 & 12 & 11 & 7 \\
\hline
\end{tabular}

Pada table diatas dapat dilihat bahwa dari 30 orang responden 27 orang (90\%) diantaranya berumur 25 - 50 tahun dan 3 orang (10\%) berumur $>50$ tahun. Responden (Perawat) yang bekerja shift adalah perempuan $(96.7 \%)$ adalah perempuan dan 1 orang (3.3\%) adalah laki-laki. Diantara responden yang sudah menikah sebanyak 25 orang (83.3\%) dan belum menikah sebanyak 5 orang (16.7\%) dan 12 orang (40\% ) diantaranya memiliki pengalaman kerja 5-10 tahun, 11 orang (3.6\%) memiliki pengalaman kerja 10-20 tahun dan 7 orang $(23.7 \%)$ memeiliki pengalaman kerja $>20$ tahun

\subsection{Tehnik Pengukuran}

Alur penelitian ini adalah pengumpulan bahan untuk tinjauan pustaka,pembuatan proposal penelitian dan permintaan prosedur perizinan penelitian ke RSUP Haji Adam Malik Medan. Setelah proses perizinan, dilakukan studi pendahuluan untuk melihat ada tidaknya kelelahan pada perawat. Pengumpulan data dengan cara Pengukuran kelelahan secara subjektif dan objektif. Pengukuran kelelahan Subjektif dengan menggunakan kuisioner International Fatique Research Comitte (IFRC) dari Japenese Association of Industrial Health of Comitte. Pengukuran kelelahan secara Objektif dengan alat Ukur Kelelahan berupa Reaction Timer Takkasidaya 77.

\subsubsection{Pengukuran Kelelahan secara Subjektif}

Mengukur Kelelahan Kerja terdiri dari 30 pertanyaan tentang gejala subjektif kelelahan. Kuisioner ini kemudian dikembangkan dimana jawaban kuisioner diskoring menjadi 4 bagian, yaitu :

- Tingkat kelelahan sangat tinggi (sangat lelah) diberi skor 4

- Tingkat kelelah tinggi diberi skor 3

- $\quad$ Agak lelah/ kelelahan sedang diberi skor 2

Tidak lelah/rendah diberi skor 1, dengan hasil pengelompokan sebagai berikut : 


\begin{tabular}{|c|c|c|c|}
\hline $\begin{array}{l}\text { Tingkat } \\
\text { Kelelahan }\end{array}$ & $\begin{array}{c}\text { Total } \\
\text { skor } \\
\text { individu }\end{array}$ & $\begin{array}{l}\text { Klasifikasi } \\
\text { kelelahan }\end{array}$ & $\begin{array}{l}\text { Tindakan } \\
\text { perbaikan }\end{array}$ \\
\hline 1 & $30-52$ & Rendah & $\begin{array}{lr}\text { Belum diperlukan } \\
\text { adanya tindakan } \\
\text { perbaikan }\end{array}$ \\
\hline 2 & 53-75 & Sedang & $\begin{array}{l}\text { Mungkin } \\
\text { diperlukan }\end{array}$ \\
\hline 3 & $76-98$ & Tinggi & $\begin{array}{l}\text { Diperlukan adanya } \\
\text { tindakan perbaikan }\end{array}$ \\
\hline 4 & $99-120$ & $\begin{array}{l}\text { Sangat } \\
\text { tinggi }\end{array}$ & $\begin{array}{l}\text { Diperlukan } \\
\text { tindakan perbaikan } \\
\text { sesegera mungkin }\end{array}$ \\
\hline
\end{tabular}

Hasil Pengukuran pada 30 orang responden yang menjalankan kerja shift, yaitu 10 orang shift pagi, 10 orang shift sore dan 10 orang shift malam. Pengukuran dilakukan 2 kali untuk setiap shift, yaitu sebelum menjalankan kerja shift ( pre) dan setelah menjalankan kkerja shift (post), yang hasilnya dapat dilihat pada table berikut:

Tabel 5.2. Distribusi Frekwensi Data Subjektif Tingkat Kelelahan Perawat Sebelum Dan Sesudah Bekerja Shift Pagi Di Ruang Rawat Inap Terpadu Interna RSUP.H.Adam Malik Medan Tahun 2016

\begin{tabular}{|c|c|c|c|c|c|c|c|c|c|c|}
\hline \multirow{2}{*}{$\begin{array}{l}\text { No } \\
\text { Kode }\end{array}$} & \multicolumn{3}{|c|}{$\begin{array}{l}\text { Klasifikasi Kuesioner Pre Test } \\
\text { Kelemahan }\end{array}$} & \multirow{2}{*}{$\begin{array}{l}\text { To } \\
\text { Tal }\end{array}$} & \multirow{2}{*}{$\begin{array}{c}\text { Klasifikasi } \\
\text { Kelela } \\
\text { han }\end{array}$} & \multicolumn{3}{|c|}{$\begin{array}{c}\text { Klasifikasi Kuesioner Post } \\
\text { Test Kelemahan }\end{array}$} & \multirow[t]{2}{*}{ To tal } & \multirow{2}{*}{$\begin{array}{c}\text { Klasifi } \\
\text { kasi Kelela } \\
\text { han }\end{array}$} \\
\hline & Aktifitas & Motivasi & Fisik & & & Aktifitas & $\begin{array}{l}\text { Moti } \\
\text { vasi }\end{array}$ & $\begin{array}{c}\mathrm{Fi} \\
\text { sik }\end{array}$ & & \\
\hline 1 & 15 & 12 & 11 & 38 & Rendah & 27 & 22 & 20 & 69 & Sedang \\
\hline 2 & 10 & 10 & 10 & 30 & Rendah & 25 & 12 & 18 & 55 & Sedang \\
\hline 3 & 27 & 24 & 21 & 72 & Sedang & 29 & 22 & 30 & 81 & Tinggi \\
\hline 4 & 19 & 24 & 16 & 59 & Sedang & 21 & 23 & 26 & 70 & Sedang \\
\hline 5 & 11 & 12 & 12 & 35 & Rendah & 11 & 12 & 12 & 35 & Rendah \\
\hline 6 & 25 & 28 & 38 & 91 & Tinggi & 27 & 21 & 33 & 81 & Sedang \\
\hline 7 & 22 & 23 & 29 & 74 & Sedang & 35 & 21 & 20 & 76 & Tinggi \\
\hline 8 & 10 & 11 & 11 & 32 & Rendah & 17 & 13 & 12 & 42 & Rendah \\
\hline 9 & 14 & 12 & 15 & 41 & Rendah & 18 & 12 & 14 & 44 & Rendah \\
\hline 10 & 12 & 10 & 10 & 32 & Rendah & 14 & 10 & 10 & 34 & Rendah \\
\hline Totall & 155 & 166 & 173 & 494 & & 224 & 178 & 195 & 587 & \\
\hline $\begin{array}{l}\text { Rata- } \\
\text { rata }\end{array}$ & 15.5 & 16.6 & 17.3 & 49.4 & Rendah & 22.4 & 17.8 & 19.5 & 58.7 & Sedang \\
\hline
\end{tabular}

Interpretasi: Berdasarkan data tersebut diketahui bahwa terdapat 4 responden (40\%) shift pagi dengan tingkat kelelahan rendah tetap/tidak mengalami perubahan tingkat kelelahan, perawat yang mengalami kelelahan sedang sebelum bekerja , pada akhir masa kerja juga juga tidak mengalami perubahan dan 2 responden dengan tingkat kelelahan rendah meningkat menjadi sedang (20\%), 2 orang responden (20\%) mengalami peningkatan keleahan sedang menjadi tinggi setelah bekerja dan 1 responden ditemui mengalami penurunan kelelahan dari klasifikasi tinggi menjadi sedang. Tingkat Kelelahan rata-rata shift pagi sebelum bekerja (pre) adalah 49.4, termasuk dalam kategori rendah dan setelah bekerja meningkatkan menjadi 58.7 yang termasuk dalam klasifikasi kelelahan sedang. Kondisi ini menunjukkan ada pengaruh kerja shift pagi terhadap kelelahan perawat dari tingkat rendah menjadi tingkat kelelahan sedang. 
Tabel 5.4. Distribusi Frekwensi Data Subjektif Tingkat Kelelahan Perawat Sebelum dan Sesudah Bekerja Pada Kerja Shift Siang Di Ruangan Rawat Inap Terpadu RSUP. H. Adam Malik Medan Tahun 2016

\begin{tabular}{|c|c|c|c|c|c|c|c|c|c|c|}
\hline \multirow[t]{2}{*}{ No kode } & \multicolumn{3}{|c|}{$\begin{array}{c}\text { Klasifikasi kuesioner pre test } \\
\text { kelemahan }\end{array}$} & \multirow{2}{*}{$\begin{array}{l}\text { To } \\
\text { Tal }\end{array}$} & \multirow[t]{2}{*}{ Klasifikasi } & \multicolumn{3}{|c|}{$\begin{array}{c}\text { Klasifikasi kuesioner post test } \\
\text { kelemahan }\end{array}$} & \multirow[t]{2}{*}{ Total } & \multirow[t]{2}{*}{ Klasifikasi } \\
\hline & Aktifitas & \begin{tabular}{|l|} 
Motivasi \\
\end{tabular} & Fisik & & & Aktifitas & Motivasi & Fisik & & \\
\hline 1 & 15 & 12 & 14 & 41 & Rendah & 27 & 22 & 20 & 69 & Sedang \\
\hline 2 & 12 & 12 & 11 & 35 & Rendah & 25 & 12 & 18 & 55 & Sedang \\
\hline 3 & 27 & 24 & 21 & 72 & Sedang & 29 & 22 & 30 & 81 & Sedang \\
\hline 4 & 17 & 24 & 16 & 57 & Sedang & 21 & 23 & 26 & 70 & Sedang \\
\hline 5 & 11 & 12 & 13 & 36 & Rendah & 11 & 12 & 14 & 37 & Sedang \\
\hline 6 & 25 & 28 & 28 & 81 & Tinggi & 27 & 21 & 33 & 71 & Rendah \\
\hline 7 & 22 & 23 & 29 & 74 & Sedang & 35 & 21 & 20 & 76 & Sedang \\
\hline 8 & 10 & 11 & 13 & 34 & Rendah & 17 & 13 & 12 & 42 & Rendah \\
\hline 9 & 14 & 12 & 15 & 41 & Rendah & 18 & 12 & 14 & 44 & Rendah \\
\hline 10 & 12 & 13 & 12 & 37 & Rendah & 14 & 10 & 10 & 34 & Sedang \\
\hline Total & 165 & 171 & 172 & 508 & & 224 & 168 & 195 & 587 & \\
\hline Ratarata & 16.5 & 17.1 & 17.2 & 50.8 & Rendah & 22.4 & 16.8 & 19.5 & 58.7 & Sedang \\
\hline
\end{tabular}

Interpretasi: Rerata tingkat kelelahan sebelum bekerja (pre) adalah 50.8 (tingkat rendah dan sesudah menjalankan kerja shift menjadi 58.7 atau dengan tingkat kelelahan sedang.

Tabel 5.5. Distribusi Frekwensi Data Subjektif Tingkat Kelelahan Perawat Sebelum Dan Sesudah Bekerja Pada Kerja Shift Malam Di Ruangan Rawat Inap Terpadu RSUP.H..Adam Malik Medan Tahun 2016

\begin{tabular}{|c|c|c|c|c|c|c|c|c|c|c|}
\hline \multirow{2}{*}{$\begin{array}{l}\text { No } \\
\text { Kode }\end{array}$} & \multicolumn{3}{|c|}{$\begin{array}{c}\text { Klasifikasi kuesioner pre test } \\
\text { kelemahan }\end{array}$} & \multirow{2}{*}{$\begin{array}{l}\text { To } \\
\text { Tal }\end{array}$} & \multirow{2}{*}{$\begin{array}{l}\text { Tingkat } \\
\text { Kelelahan }\end{array}$} & \multicolumn{3}{|c|}{$\begin{array}{l}\text { Klasifikasi kuesioner post test } \\
\text { kelemahan }\end{array}$} & \multirow{2}{*}{$\begin{array}{l}\text { To } \\
\text { tal }\end{array}$} & \multirow{2}{*}{$\begin{array}{l}\text { Tingkat } \\
\text { Kelelahan }\end{array}$} \\
\hline & Aktifitas & Motivasi & Fisik & & & Aktifitas & Motivasi & $\begin{array}{c}\mathrm{Fi} \\
\text { sik }\end{array}$ & & \\
\hline 1 & 15 & 16 & 11 & 42 & Rendah & 20 & 38 & 42 & 100 & Sangat tinggi \\
\hline 2 & 11 & 12 & 12 & 35 & Rendah & 18 & 15 & 13 & 46 & Rendah \\
\hline 3 & 23 & 22 & 10 & 55 & Sedang & 32 & 34 & 40 & 106 & Sangat tinggi \\
\hline 4 & 25 & 12 & 16 & 53 & Sedang & 29 & 12 & 21 & 62 & Sedang \\
\hline 5 & 16 & 14 & 14 & 44 & Rendah & 35 & 32 & 38 & 105 & Sangat tinggi \\
\hline 6 & 12 & 12 & 14 & 38 & Rendah & 22 & 24 & 17 & 63 & Sedang \\
\hline 7 & 16 & 13 & 14 & 43 & Rendah & 28 & 17 & 22 & 67 & Sedang \\
\hline 8 & 14 & 14 & 18 & 46 & Rendah & 28 & 18 & 32 & 78 & Tinggi \\
\hline 9 & 21 & 23 & 12 & 56 & Sedang & 29 & 30 & 35 & 94 & Tinggi \\
\hline 10 & 16 & 10 & 14 & 40 & Rendah & 18 & 12 & 20 & 50 & Rendah \\
\hline Total & 169 & 148 & 135 & 452 & & 259 & 232 & 280 & 771 & \\
\hline Ratarata & 16.9 & 4.8 & 13.5 & 45.2 & Rendah & 25.9 & 23.2 & 28.0 & 77.1 & Tinggi \\
\hline
\end{tabular}

Interpretasi: Berdasarkan data tersebut diketahui bahwa terdapat 2 orang responden yang tidak mengalami peningkatan kelelahan, yaitu 2 responden (20\%) dengan tingkat kelelahan rendah, dan 1 responden (10\%) dengan tingkat kelelahan sedang. Responden yang merasa kelelahan rendah yang dialami 2 orang responden sebelum menjalankan kerja shift malam, dan seorang responden yang merasakan kelelahan sedang setelah menjalankan shift malam (post) merasakan kelelahan sangat tinggi (30\%). Sementara responden dengan kelelahan tinggi dialami oleh 2 orang responden (20\%), yang sebelum bekerja (pre) mengalami tingkat kelelahan sedang dan rendah.Kelelahan rendah menjadi sedang setelah menjalani kerja shift malam. Rerata tingkat kelelahan yang dirasakan perawat sebelum (pre) melaksanakan kerja shift malam adalah 45.2 (tingkat kelelahan rendah dan setelah menjalankan kerja shift malam menjadi 77.1 (tingkat kelelahan tinggi)

\subsubsection{Pengukuran Objektif}

Hasil pengukuran kelelahan secara Objektif dengan alat Ukur Kelelahan berupa Reaction Timer Lakkasidaya 77, menghasilkan Analisa sebagai berikut:

1. Analisis Univariat

Analisa Univariat terhadap responden disajikan dalam bentuk table distribusi frekuensi, berdasarkan jenis kelamin responden, disajikan dalam tabel berikut :

Tabel 5.6 Distribusi $\quad$ Frekuensi Responden berdasarkan Jenis Kelamin di Di Ruang Rawat Inap Terpadu Interna RSUP.H.Adam Malik Medan Tahun 2016

\begin{tabular}{|ll|r|r|r|r|}
\hline & & Frequency & Percent & $\begin{array}{c}\text { Valid } \\
\text { Percent }\end{array}$ & $\begin{array}{c}\text { Cumulative } \\
\text { Percent }\end{array}$ \\
\hline Valid & Pria & 1 & 3,3 & 3,3 & 3,3 \\
& Wanita & 29 & 96,7 & 96,7 & 100,0 \\
& Total & 30 & 100,0 & 100,0 & \\
\hline
\end{tabular}

Tabel menunjukkan responden terdiri 29 orang wanita (96.7\%) dan 1 orang pria (3.3\%) 
Tabel 5.7 Distribusi $\quad$ Frekuensi $\quad$ Responden berdasarkan Index Massa Tubuh (IMT) Di Ruang Rawat Inap Terpadu Interna RSUP.H.Adam Malik Medan Tahun 2016

\begin{tabular}{|ll|r|r|r|r|}
\hline & & & & Valid & Cumulative \\
& & Frequency & Percent & Percent & Percent \\
\hline Valid & Gizi Baik & 13 & 43,3 & 43,3 & 43,3 \\
& GiziLebih & 17 & 56,7 & 56,7 & 100,0 \\
& Total & 30 & 100,0 & 100,0 & \\
\hline
\end{tabular}

Berdasarkan table 5.7. dapat dilihat Responden dengan gizi lebih berjumlah 17 orang (56.7\%) dan gizi baik sebanyak 13 orang (43.3\%)

Tabel 5.8 Distribusi Frekuensi Klasifikasi Kelelahan Responden Sebelum Bekerja (Pre test) Di Ruang Rawat Inap Terpadu Interna RSUP.H.Adam Malik Medan Tahun 2016

\begin{tabular}{|ll|r|r|r|r|}
\hline & Frequency & Percent & $\begin{array}{c}\text { Valid } \\
\text { Percent }\end{array}$ & $\begin{array}{c}\text { Cumulative } \\
\text { Percent }\end{array}$ \\
\hline Valid & Kelelahan & 20 & 66,7 & 66,7 & 66,7 \\
& $\begin{array}{l}\text { Rendah } \\
\text { Kelelahan }\end{array}$ & 9 & 30,0 & 30,0 & 96,7 \\
Sedang & 1 & 3,3 & 3,3 & 100,0 \\
Kelelahan & 30 & 100,0 & 100,0 & \\
Tinggi & & \\
Total & &
\end{tabular}

Berdasarkan table 5.8. dapat dilihat klasifikasi kelelahan responden sebelum melaksanakan kerja shift 20 responden mengalami kelelahan ringan (66.7\%), dan yang mengalami kelelahan sedang 9 orang (30.0\%) dan 1 orang yang mengalami kelelahan tinggi (3.3\%).
Tabel 5.9 Distribusi Frekuensi Klasifikasi Kelelahan Responden Setelah Bekerja (Post test) Di Ruang Rawat Inap Terpadu Interna RSUP.H.Adam Malik Medan Tahun 2016

\begin{tabular}{|c|c|c|c|c|c|}
\hline & & Frequency & Percent & $\begin{array}{l}\text { Valid } \\
\text { Percent }\end{array}$ & $\begin{array}{c}\text { Cumulative } \\
\text { Percent }\end{array}$ \\
\hline \multirow[t]{7}{*}{ Valid } & $\begin{array}{l}\text { Kelelahan } \\
\text { Rendah }\end{array}$ & 8 & 26,7 & 26,7 & 26,7 \\
\hline & Kelelahan & 13 & 133 & 433 & 700 \\
\hline & Sedang & 15 & 45, & 45,J & 10,0 \\
\hline & Kelelahan & 5 & 16,7 & 16,7 & 86,7 \\
\hline & Kelelahan & & & & \\
\hline & $\begin{array}{l}\text { sangat } \\
\text { tinggi }\end{array}$ & 4 & 13,3 & 13,3 & 100,0 \\
\hline & Total & 30 & 100,0 & 100,0 & \\
\hline
\end{tabular}

Berdasarkan table 5.9 dapat dilihat klasifikasi kelelahan Responden setelah menjalankan shift kerja 8 orang responden mengalami kelelahan ringan (26.7\%), mengalami kelelahan sedang 13 orang (43.3\%),5 orang yang mengalami kelelahan tinggi (16,7\%) dan Responden yang mengalami kelelahan sangat tinggi sebanyak 4 Orang $(13.3 \%)$.

\section{Analisa Bivariat}

Untuk melihat apakah terdapat perbedaan klasifikasi kelelahan pada Responden yang menjalankan kerja shift di analisa dengan menggunakan uji $t$ berpasangan yang hasilnya dsajikan pada tabel berikut :

Tabel 5.10. Distribusi Frekuensi Klasifikasi Perbedaan Kelelahan Responden sebelum (Pre) dan sesudah (post) Menjalankan Kerja shift pagi di Ruang Rawat Inap Terpadu RSUP Haji Adam Malik Medan Tahun 2016

\begin{tabular}{|c|c|c|c|c|c|c|c|c|}
\hline & \multicolumn{5}{|c|}{ Paired Differences } & \multirow[b]{3}{*}{ Mean } & \multirow{3}{*}{$\begin{array}{c}\text { df } \\
\\
\text { Std. } \\
\text { Deviation }\end{array}$} & \multirow{3}{*}{$\begin{array}{c}\begin{array}{c}\text { Sig. (2- } \\
\text { tailed) }\end{array} \\
\\
\text { Std. } \\
\text { Error } \\
\text { Mean } \\
\end{array}$} \\
\hline & \multirow[b]{2}{*}{ Mean } & \multirow{2}{*}{$\begin{array}{c}\text { Std. } \\
\text { Deviation }\end{array}$} & \multirow{2}{*}{$\begin{array}{l}\text { Std. Error } \\
\text { Mean }\end{array}$} & \multicolumn{2}{|c|}{$\begin{array}{l}\text { 95\% Confidence } \\
\text { Interval of the } \\
\text { Difference }\end{array}$} & & & \\
\hline & & & & Lower & Upper & & & \\
\hline $\begin{array}{ll}\text { Pair } & \begin{array}{l}\text { KlasifikasiKelelahan } \\
1\end{array} \\
& \text { (Pre Test) - } \\
& \text { KlasisikasiKelelahan } \\
& \text { (Post Test) }\end{array}$ &,- 400 & ,516 & 163 &,- 769 &,- 031 & $-2,449$ & 9 & ,037 \\
\hline
\end{tabular}

Dari table diatas dapat diliihat rata-rata nilai total kelelahan sebelum menjalankan kerja shift dan sesudah menjalankan kerja shift pagi diketahui bahwa $\alpha$ Sig. (2-tailed) $=0.37$, artinya lebih kecil dari 0.05 yang artinya yang artinya tidak ada perbedaan rerata kelelahan pada perawat sebelum dan sesudah bekerja shift pagi.

Tabel 5.11. Distribusi Frekuensi Klasifikasi Perbedaan Kelelahan Responden sebelum (Pre) dan sesudah (post) Menjalankan Kerja shift Siang Di Ruang Rawat Inap Terpadu Interna RSUP.H.Adam Malik Tahun 2016

\begin{tabular}{|c|c|c|c|c|c|c|c|c|c|}
\hline & & \multicolumn{5}{|c|}{ Paired Differences } & \multirow{3}{*}{$\begin{array}{c}\mathrm{t} \\
\text { Mean }\end{array}$} & \multirow{3}{*}{$\begin{array}{c}\text { df } \\
\\
\text { Std. } \\
\text { Deviation }\end{array}$} & \multirow{3}{*}{$\begin{array}{c}\text { Sig. (2-tailed) } \\
\text { Std. Error Mean }\end{array}$} \\
\hline & & \multirow[b]{2}{*}{ Mean } & \multirow{2}{*}{$\begin{array}{c}\text { Std. } \\
\text { Deviation }\end{array}$} & \multirow{2}{*}{$\begin{array}{l}\text { Std. Error } \\
\text { Mean }\end{array}$} & \multicolumn{2}{|c|}{$\begin{array}{l}\text { 95\% Confidence } \\
\text { Interval of the } \\
\text { Difference }\end{array}$} & & & \\
\hline & & & & & Upper & Lower & & & \\
\hline Pair 1 & $\begin{array}{l}\text { KlasifikasiKelel } \\
\text { ahan (Pre Test) - } \\
\text { KlasisikasiKelel } \\
\text { ahan (Post Test) }\end{array}$ &,- 700 & ,675 & ,213 & $-1,183$ &,- 217 & $-3,280$ & 9 & ,010 \\
\hline
\end{tabular}


Dari table diatas dapat dilihat perbedaan rata-rata nilai total kelelahan sebelum menjalankan kerja shift dan sesudah menjalankan kerja shift siang diketahui bahwa $\alpha$ Sig. (2-tailed) $=0.010$, artinya lebih kecil dari 0.05 yang artinya tidak ada perbedaan rerata kelelahan pada perawat sebelum dan sesudah bekerja shift siang.

Tabel 5.12. Distribusi Frekuensi Klasifikasi Perbedaan Kelelahan Responden sebelum (Pre) dan sesudah (post) Menjalankan Kerja shift Malam di Di Ruang Rawat Inap Terpadu Interna RSUP Haji Adam Malik Medan Tahun 2016

\begin{tabular}{|c|c|c|c|c|c|c|c|c|}
\hline & \multicolumn{4}{|c|}{ Paired Differences } & $\mathrm{t}$ & $\mathrm{df}$ & & \\
\hline & \multirow[b]{2}{*}{ Mean } & \multirow{2}{*}{$\begin{array}{c}\text { Std. } \\
\text { Deviation }\end{array}$} & \multirow{2}{*}{$\begin{array}{l}\text { Std. Error } \\
\text { Mean }\end{array}$} & $\begin{array}{l}\text { 95\% Confidence } \\
\text { Interval of the } \\
\text { Difference }\end{array}$ & \multirow[b]{2}{*}{ Mean } & \multirow{2}{*}{$\begin{array}{c}\text { Std. } \\
\text { Deviation }\end{array}$} & \multirow{2}{*}{\multicolumn{2}{|c|}{$\begin{array}{l}\text { Sig. (2-tailed) } \\
\text { Std. Error Mean }\end{array}$}} \\
\hline & & & & & & & & \\
\hline $\begin{aligned} \text { Pair } 1 & \text { KlasifikasiKelelahan } \\
& \text { (Pre Test) } \\
& \text { KlasisikasiKelelahan } \\
& \text { (Post Test) }\end{aligned}$ & $-1,300$ & 1,160 & 367 & $-2,129$ &,- 471 & $-3,545$ & 9 & ,006 \\
\hline
\end{tabular}

Dari table diatas dapat dilihat perbedaan rata-rata nilai total kelelahan sebelum menjalankan kerja shift dan sesudah menjalankan kerja shift malam diketahui bahwa $\alpha$ Sig. (2-tailed) $=0.010$, artinya lebih kecil dari 0.05 , yang artinya tidak ada perbedaan rerata kelelahan pada perawat sebelum dan sesudah bekerja shift malam.

\subsection{Pembahasan}

Mengukur kelelahan ini dilakukan dengan menggunakan IFRC, berupa Kuisioner yang terdiri dari 30 pertanyaan untuk mengukur tingkat kelelahan.Sepuluh item pertama mengindikasikan adanya pelemahan aktivitas, 10 item kedua pelemahan motivasi kerja dan 10 item ketiga pelemahan mengindikasikan kelelahan fisik atau kelelahan pada beberapa bagian tubuh. Semakin tingggi frekuensi gejala kelelahan muncul diartikan semakin besar pula tingkat kelelahan. Berdasarkan desain penilaian kelelahan subjektif ini akan diperoleh skor individu terendah 30 dan skor individu tertinggi 120 dan aplikasi kuesioner ini adalah melakukan upaya perbaikan pada pekerjaan, jika diperoleh hasil yang menunjukkan tinggi

\subsection{Pembahasan}

5.4.1. Hasil Pengukuran dengan Kuesioner IFRC, ditemui kondisi sebagai berikut :

\section{Kerja Shift pagi}

Berdasarkan data tersebut diketahui bahwa terdapat 4 responden (40\%) shift pagi dengan tingkat kelelahan rendah tetap/tidak mengalami perubahan tingkat kelelahan, perawat yang mengalami kelelahan sedang sebelum bekerja , pada akhir masa kerja juga juga tidak mengalami perubahan dan 2 responden dengan tingkat kelelahan rendah meningkat menjadi sedang (20\%), 2 orang responden (20\%) mengalami peningkatan kelelahan sedang menjadi tinggi setelah bekerja dan 1 responden ditemui mengalami penurunan kelelahan dari klasifikasi tinggi menjadi sedang.

Tingkat Kelelahan rata-rata shift pagi sebelum bekerja (pre) adalah 49.4, termasuk dalam kategori rendah dan setelah bekerja meningkatkan menjadi 58.7 yang termasuk dalam klasifikasi kelelahan sedang. Kondisi ini menunjukkan ada pengaruh kerja shift pagi terhadap kelelahan perawat dari tingkat rendah menjadi tingkat kelelahan sedang tetapi untuk tingkat kelelahan sedang menurut International Fatique Research Comitte (IFRC) mungkin diperlukan tindakan perbaikan, untuk itu masih perlu dilakukan pengamatan lebih lanjut.

\section{Kerja shift Siang}

Berdasarkan data yang diperoleh diketahui bahwa terdapat 5 responden shift sore dengan tingkat kelelahan tetap / tidak mengalami perubahan tingkat kelelahan dan ditemui 5 responden yang mengalami peningkatan kelelahan dari rendah menjadi sedang, dan tidak ditemui responden yang mengalami kelelahan yang tinggi. Rerata tingkat kelelahan sebelum bekerja (pre) adalah 50.8 (tingkat rendah) dan sesudah menjalankan kerja shift menjadi 58.7 atau dengan tingkat kelelahan sedang.

Untuk tingkat kelelahan sedang perlu dikaji lebih lanjut, antara lain jumlah pasien yang dirawat, tingkat ketergantungan pasien. International Fatique Research Comitte (IFRC) menyatakan mungkin diperlukan tindakan perbaikan. Menurut teori Loveridge and Cumming (1996 dalam Gillies,2007) bahwa pasien dengan tingkat ketergantungan total membutuhkan perawat 5 -6 jam / 24 jam,berarti untuk tiap shift $\pm 1,5-2$ jam kebutuhan pasien akan pertolongan perawat.

Berdasarkan penghitungan tersebut perawat shift dengan lama kerja 8 jam, seharusnya perawat di ruangan yang mengalami kelelahan yang tinggi. Hal ini mungkin disebabkan angka ketergantungan kebutuhan pasien akan pertolongan perawat adalah kondisi pasien dengan ketergantungan minimal rendah.

\section{Kerja Shift Malam}

Hasil pengukuran kelelahan subjektif didapatkan rerata tingkat kelelahan yang dirasakan perawat sebelum (pre) melaksanakan kerja shift malam adalah 45.2 (tingkat kelelahan rendah dan setelah menjalankan kerja shift malam menjadi 77.1 (tingkat kelelahan tinggi).. Menurut International Fatique Research Comitte, kondisi ini memerlukan adanya tindakan perbaikan.

Shift malam menyebabkan gangguan irama tubuh (circadian rhythms) dapat menimbulkan kerugian terhadap kemampuan fisik dan mental pekerja shift, khususnya ketika perubahan shift kerja. Tipe pekerja. Untuk contoh, pekerja yang telah berusia tua memiliki 
kemampuan yang minimal untuk untuk menstabilkan irama tubuh ketika perubahan shift kerja. Dalam penyusunan jadwal shift kerja ada beberapa saran yang harus diperhatikan dalam penyusunan jadwal:

1. Pekerja shift malam sebaiknya berumur 25-50 tahun

2. Pekerja yang cenderung punya penyakit di perut dan usus, serta yang punya emosi tidak stabil disarankan utk tidak ditempatkan di shift malam

3. Pekerja yang tinggal jauh dari tempat kerja atau berada dilingkungan ramai tidak dapat bekerja malam

4. Sistem shift 3 rotasi sebaiknya pukul 07.00-5.0023.00 atau $08.00-16.00-24.00$

5. Rotasi pendek lebih baik daripada rotasi panjang dan harus dihindarkan kerja malam secara terus menerus

6. Rotasi yang baik 2-2-2 (metropolitan pola atau 22-3 (continental pola)

7. Kerja malam 3 hari berturut-turut harus segera diikuti istirahat paling sedikit 24 jam

8. Perencanaan shift meliputi akhir pekan dengan 2 hari libur berurutan

9. Tiap shift terdiri dari satu kali istirahat yang cukup utk makan

\subsubsection{Analisis hasil Pemeriksaan Laboratorium Ergonomi}

1. Analisis Uni variat

Pengukuran Kelelahan dengan Reaction Timer Lakassidaya 77, dan dilakukan analisa dengan t-test berpasangan didapati klasifikasi kelelahan responden sebelum melaksanakan kerja shift 20 responden mengalami kelelahan ringan (66.7\%), dan yang mengalami kelelahan sedang 9 orang (30.0\%) dan 1 orang yang mengalami kelelahan tinggi (3.3\%), dan setelah menjalankan shift kerja 8 orang responden mengalami kelelahan ringan (26.7 \%), mengalami kelelahan sedang 13 orang (43.3\%) ,5 orang yang mengalami kelelahan tinggi (16,7\%) dan Responden yang mengalami kelelahan sangat tinggi sebanyak 4 Orang (13.3\%)

\section{Analisa Bivariat}

\section{a. Shift Pagi}

Untuk melihat apakah terdapat perbedaan klasifikasi kelelahan pada Responden yang menjalankan kerja shift di analisa dengan menggunakan uji t berpasangan yang hasilnya rata-rata nilai total kelelahan sebelum menjalankan kerja shift dan sesudah menjalankan kerja shift pagi diketahui bahwa $\alpha$ Sig. (2-tailed) $=0.37$, artinya lebih kecil dari 0.05 yang artinya yang artinya tidak ada perbedaan rerata kelelahan pada perawat sebelum dan sesudah bekerja shift pagi.

\section{b. Shift Siang}

Perbedaan rata-rata nilai total kelelahan sebelum menjalankan kerja shift dan sesudah menjalankan kerja shift siang diketahui bahwa $\alpha$ Sig. (2-tailed) $=0.010$, artinya lebih kecil dari 0.05 yang artinya tidak ada perbedaan rerata kelelahan pada perawat sebelum dan sesudah bekerja shift siang

\section{c. Shift Malam}

Perbedaan rata-rata nilai total kelelahan sebelum menjalankan kerja shift dan sesudah menjalankan kerja shift malam diketahui bahwa $\alpha$ Sig. (2-tailed) $=0.010$, artinya lebih kecil dari 0.05 , yang artinya tidak ada perbedaan rerata kelelahan pada perawat sebelum dan sesudah bekerja shift malam.

\section{KESIMPULAN \& SARAN}

\subsection{Kesimpulan}

1 Pada Pengukuran Subjektif ada pengaruh kerja shift terhadap kelelahan Perawat yang menjalankan kerja shift dan Kelelahan tertinggi didapai pada perawat yang menjalankan kerja shift malam

2 Pada Analisa pengukuran objektif tidak ada pengaruh kerja shift pagi, kerja shift sore dan kerja shift malam terhadap kelelahan di Ruang Rawat Inap Terpadu RSUP Haji Adam Malik Medan

\subsection{Saran}

1. Mengkaji ulang jumlah dan kualifikasi personil perawat kerja shift malam sebab kelelahan yang paling tinggi terjadi pada shift malam.

2. 2.Memberi waktu istirahat secara bergantian dalam shift kerja untuk menurunkan kelelahan sebagaimana diatur dalam UU Ketenagakerjaan.

3. 3.Perawat memelihara gaya hidup sehat dengan mengatur kebutuhan istirahat dan aktivitas yang seimbang.

\section{DAFTAR PUSTAKA}

Alimul, Azis. 2006. Riset Keperawatan dan Teknik Penulisan Ilmiah. Jakarta: Salemba Medika

Arikunto, Suharsimi, 2008, Prosedur Penelitian, Jakarta, Rineka Cipta

Dahlan, M.Sopiyuddin, 2003, Besar Sample dan Cara pengamblan sampell dalam Penelitian Kedokteran dan Kesehatan, Edisi 3, seri Evidence Based Medicine 2, Salemba Medika, Jakarta

Eko N, Ergonomic Konsep Dasar dan Aplikasinya, Surabaya

Granjean, Fitting the Task to The Man, 1998,

https://hiukencana.wordpress.com/2010/03/31/kelelahankerja-occupational-fatigue/ 13/10 2016

Lientje Setyawati, Kelelahan Kerja Khronis, Kajian Terhadap Kelelahan Kerja, Penyusunan Alat Ukur serta Hubungannya dengan Waktu Reaksi dan Produktivitas Kerja, 1999, Disertasi,Tidak diterbitkan, Jogyakarta

Notoatmojo Soekijo, 2010, Metodologi Penelitian Kesehatan, Rineka Cipta, Jakarta

Nurmianto,Eko.Ergonomi,Konsep Dasar Dan Aplikasinya.Surabaya:Prima Printing .2008

S.Wijnjosoebroto, Ergonomi,Studi Gerak dan Waktu Tehnik Analisis untuk Peningkatan Produktivitas Kerja, Surabaya, Guna Widya, 2003

Tarwaka, dkk, Ergonomi untuk Keselamatan dan Kesehatan Kerja dan Produktivitas, Surakarta, Unipress, 2004 